\title{
Nomes, Posições e (contra) Hierarquia: coletivos em transformação no Alto Rio Negro
}

\author{
Geraldo Andrello \\ Universidade Federal de São Carlos, São Paulo, Brasil \\ E-mail: andrello@ufscar.br
}




\section{Resumo}

Este artigo explora o modo e as categorias pelas quais são agenciadas as diferenças internas ao grande conjunto multiétnico e multilinguístico do noroeste amazônico e, em particular, do rio Uaupés. Na etnografia da região, essas diferenças são, normalmente, descritas como distinções de hierarquia, expressas pela atribuição de status ritual diferenciado a pessoas e coletivos de acordo com a ordem de surgimento de seus ancestrais clânicos. Em uma primeira parte do texto, foram retomadas algumas informações disponíveis nas fontes históricas dos séculos XVIII e XIX acerca da etnonímia da região. Em seguida, são elaboradas hipóteses acerca desse fenômeno a partir de um exemplo etnográfico atual. Tudo isso para sugerir que, paralelamente à profusão de nomes particulares associados à origem mítica dos clãs patrilineares, a recorrência de umas poucas categorias englobantes dizem respeito a posições instáveis e contrastivas, ora ativamente perseguidas, ora rejeitadas. Busca-se, assim, colocar em evidência uma dinâmica social na qual as diferenças hierárquicas dizem respeito, de fato, a um componente metaestável intrínseco a esse sistema, e balizado por um gradiente virtual que oscila entre humanidade e não humanidade.

Palavras-chave: Hierarquia. Etnônimos. Nominação. Formação de Grupos. Noroeste Amazônico.

\section{Abstract}

This article explores the way and the categories with which the internal differences to large multi-ethnic and multi-lingual social system of the Northwestern Amazon are worked out, and in particular in Uaupés river. In the ethnography of the region these differences are generally described as hierarchical distinctions expressing different ritual status of individuals and groups according to the order of appearance of their clan ancestors. In the first part of the article, I deal with some information available in the historical sources of the eighteenth and nineteenth centuries about the ethnonyms of the region. Then I will elaborate hypotheses about this phenomenon from a current ethnographic example. All this to suggest that, in addition to the profusion of particular names associated with the mythical origin of patrilineal clans, the recurrence a few encompassing categories have to do with unstable and contrasting positions, sometimes actively pursued, other times rejected. The intent is to highlight a social dynamic in which the hierarchical differences concern, in fact, a metastable intrinsic component to the system marked by a virtual gradient between humanity and non-humanity.

Keywords: Hierarchy. Ethnonyms. Naming. Formation of Groups. Northwest Amazon. 


\section{Introdução}

If recurse is made to Spanish to explain a hierarchical arrangement, an informant will say something like "Este grupo tiene três grupos". In Tukano he would say, "This group is threegroups: the Anteater people are three-groups: the $\mathrm{A}$ are at $\mathrm{X}$ rapids, the $\mathrm{B}$ are at $\mathrm{Y}$ stretch of the Papuri river, and the $\mathrm{C}$ are at Z mission village." (Arthur Sorensen, 1967)

$\mathrm{E}$ ste artigo explora um aspecto marcante da vida social dos povos indígenas rionegrinos: a grande quantidade de categorias de que lançam mãos os atores locais, hoje e no passado, para designar grupos e subgrupos ${ }^{1}$. Uma das hipóteses centrais é a de que a dinâmica entre nomes e apelidos mais ou menos englobantes e as formas de tratamento que implicam são instrumentos fundamentais na conceituação de diferenças internas a esse grande conjunto multiétnico e multilinguístico, cuja homogeneidade sociológica e cultural vem sendo reafirmada em um conjunto de etnografias recentes (Lasmar, 2005; Andrello, 2006; Cabalzar, 2008; Cayón, 2009; Maia, 2009; Dias Cabalzar, 2010; Loli, 2010). De um modo mais amplo, a etnografia regional, que remonta à primeira metade do século XX, aponta em seu conjunto para o idioma da hierarquia como meio de expressão privilegiado dessas diferenciações. Idioma que, por sua vez, baseia-se em noções relativas à ordem de nascimento - o surgimento dos ancestrais míticos e sua localização-fixação originária no eixo montante-jusante do rio Negro e seus afluentes Uaupés, Içana e Xié. Busca-se, portanto, mostrar que o entendimento dessa noção local de hierarquia deve necessariamente atentar para as categorias de que lançam mão os atores locais para designar a si e a outrem, em um contexto do qual participam vários povos indígenas pertencentes às famílias linguísticas tukano arawak e maku². 
Coerente com a profusão de designações coletivas verificadas na região, as formas de dispersão dos grupos por grandes extensões territoriais assumem feições diversas, constituindo objeto privilegiado das narrativas sobre movimentos, deslocamentos e migrações de clãs ou de conjuntos clãs por meio do espaço e do tempo. A imagem de um fluxo de grupos e subgrupos, de processos inversos de amálgama e fragmentação emerge, de fato, da etnografia regional desde as primeiras monografias, ainda que na maior parte delas o esforço tenha sido o de isolar certas categorias - como fratrias, grupos exogâmicos, clãs ou sibs, papéis rituais fixos e assim por diante - para delinear posições fixas em um modelo englobante e hierarquizado de estrutura social, em geral rebatido sobre o território. Mas sua aplicação enfrenta dificuldades persistentes quando se trata de examinar as designações que essas unidades sociais atribuem-se entre si. Ou seja, diferença e hierarquia são sem dúvida noções associadas no rio Negro, mas como lidar com os juízos divergentes que frequentemente esses grupos oferecem acerca de suas distinções hierárquicas e de seus territórios de fixação e crescimento. Em suma, qual é o conteúdo dessa noção local de hierarquia? Quais princípios subjazem ao manejo das categorias recíprocas acionadas pelos atores locais? O que eles nos ensinam sobre a própria natureza das unidades sociais rionegrinas? Essas são as questões às quais tentaremos nos aproximar.

Assim, o experimento proposto aqui se concentra inicialmente na conformação da atual etnonímia do alto rio Negro, procedendo em seguida a um balanço de dados oriundos das fontes históricas balizado (ou controlado) por um exemplo etnográfico do Uaupés contemporâneo. Trata-se de verificar em que medida a recusa em aceitar certos tratamentos ou tacitamente aprová-los corresponde à negação ou à afirmação de posições de status, isto é, em que medida adotar ou alterar um nome atribuído por outrem codificam disputas e transformações no interior de uma escala comum de pessoas e coletivos. Como se verá, a coexistência de nomes genéricos e particulares associa-se a conceitos locais de ancestralidade e posição socioespacial, e seu agenciamento envolve, por um lado, a autoatribuição de nomes próprios a pessoas e coletivos, e, por outro, a atribuição por terceiros de epítetos-apelidos 
jocosos. Revelar nomes próprios, ou eclipsá-los por meio de categorias englobantes e pejorativas, parecem integrar assim um mecanismo pelo qual coletivos podem aparecer em diferentes graus de proeminência e magnitude. Suas fontes são as narrativas de origem, crescimento e dispersão, o mito e a história, por assim dizer. Isto é, os relatos que ainda abundam no rio Negro acerca da saga de uma pré-humanidade e de uma história política interminável, subsequentemente vivida por coletivos humanos que, no presente, se dão a ver de modo extremamente variado. É principalmente nessas narrativas que os argumentos elaborados ao final se inspiram.

\section{Primeiros Nomes}

As primeiras informações acerca dos nomes dos grupos indígenas que habitavam a bacia do rio Negro antes do início do processo de colonização provêm de uma documentação histórica tristemente célebre. Trata-se dos registros de escravos indígenas "resgatados" por tropas militares portuguesas em meados do século XVIII. As aspas ressaltam o eufemismo. Cativos, uma vez resgatados de uma suposta escravidão, continuariam escravos para saldar sua dívida de liberdade para com o novo colonizador - supunha-se ou queria se supor que o destino dos cativos das guerras indígenas era o canibalismo. Mas, na verdade, as chamadas guerras justas movidas pelos portugueses contra os chamados "gentios do sertão do rio Negro" prestavam-se, sobretudo, a abastecer com mão de obra indígena a colônia do Grão-Pará e Maranhão, particularmente sua capital Belém. Evidência disso é que os anos de maior intensidade do tráfico de escravos coincidem com os momentos em que as epidemias grassam nas imediações de Belém. Estimativas feitas acerca do número escravos variam significativamente, mas é certo que um enorme contingente indígena foi deslocado compulsoriamente da porção norte-ocidental da Amazônia pela via de seu principal eixo fluvial [Solimões/Japurá-Negro-Amazonas]. Robin Wright (2005) sugere que teriam sido mais de 20.000 escravos entre as décadas de 1740 e 1750, mas uma avaliação mais acurada está fora de cogitação, em função das lacunas e do caráter parcial da documentação disponível ${ }^{3}$. 
Não obstante, das amostras disponíveis na documentação sabe-se que no período delimitado pela guerra contra os Manáo por volta de 1730, termo que se referia aos povos do Baixo Rio Negro, e a decretação do fim da escravidão indígena pelo Marquês de Pombal em 1759, cerca de metade dos escravos que foram desembarcados em Belém era oriunda do rio Negro ${ }^{4}$. As informações sobre essa gente são incompletas, tanto acerca de sua localização precisa - já que os mapas começavam a ser desenhados - quanto das "nações" a que pertenceriam. Mas há um detalhe que chama a atenção: as informações acerca dos grupos escravizados podem ser distribuídas em dois conjuntos bem notáveis - um pequeno conjunto de quatro ou cinco categorias cobre mais da metade do contingente escravizado, ao passo que há centenas de outros nomes que, aplicados apenas umas poucas vezes (em certos casos a apenas um ou dois escravos), referem-se a um contingente significativamente menor. Ou seja, um pequeno conjunto de nomes aparentemente genéricos ao lado de uma profusão de designações pontuais e/ou locais. A marca distintiva do primeiro conjunto é sua permanência histórica, pois as quatro ou cinco categorias que englobam vieram a se constituir como etnônimos em uso até os dias de hoje: Baniwa, Warekena, Maku, Baré e Uaupés. Já o segundo conjunto refere-se a uma lista heteróclita de cerca de 290 categorias que, em sua quase absoluta totalidade, vieram a cair em desuso na regiãos. Wright (2005) sugere que a grande quantidade de termos do segundo conjunto explica-se pelo fato de referirem-se, em muitos casos, a aldeias, rios ou outras localidades específicas; ou ainda a nomes de chefes atribuídos, ou correntemente utilizados, como designação de coletivos inteiros. A partir do final do século XVIII e ao longo da primeira metade do século XIX, esses números caem e começam a surgir os primeiros levantamentos mais sistemáticos. Não obstante, os termos genéricos continuam a figurar nas novas listas ${ }^{6}$.

Desse rápido sobrevoo pelas fontes de meados do século XVIII e meados do século XIX, é preciso observar o seguinte: do período de um século de duração da primeira e violenta fase de contato com o colonizador não parece restar dúvidas quanto ao desaparecimento de uma quantidade praticamente inestimável de povos que habitavam 
o rio Negro e seus formadores, os rios Uaupés, Içana e Xié. É isso que parece atestar a evolução da ordem de grandezas que se verifica quanto aos nomes de grupos presentes do XVIII e do XIX. Isto é, passa-se da escala das centenas para a das dezenas. Se, até por volta dos anos de 1760, o fenômeno pode ser explicado pelo tráfico de escravos para o baixo Amazonas, a partir de então a implantação de aldeamentos ao longo do curso do rio Negro, preconizado pelo Diretório Pombalino, irá promover em larga escala os chamados "descimentos", no contexto dos quais diversos grupos localizados nos rios Uaupés, Içana e Xié passam a ser deslocados para as novas povoações. De escravos a serem resgatados, passam a súditos potenciais da coroa portuguesa, em um contexto de disputa de fronteira com a Espanha. Deslocamentos, fugas, fixação e um novo programa de emprego da mão de obra indígena vêm, senão intensificar, dar continuidade a um quadro movente no qual uma profusão de nomes e categorias surge e ressurge em lugares diferentes e sem lógica aparente. Fato notável, no entanto, é que ainda que extremamente reduzida em sua magnitude, a diversidade de termos não deixa, passado esse primeiro século violências, de impressionar pela quantidade. Muitos nomes, sem dúvida, que sugerem muitas mortes e dizimação. Extinção física inquestionável é fato certo, mas seria possível deduzir daí uma perda equivalente em termos de diversidade social? Talvez sim, mas em que medida? Impossível saber. Especulemos, portanto.

As listas de termos disponíveis nas fontes correspondem a traduções ou adaptações de palavras das antigas línguas arawak faladas no rio Negro e em boa parte de seus afluentes para o nhengatu, a língua geral de origem tupi introduzida na região pelos primeiros missionários. Há também termos traduzidos para essa língua que se referem a designações coletivas originalmente presentes nas línguas tukano do rio Uaupés ${ }^{7}$. Tal diversidade sociolinguística inviabiliza qualquer tentativa de explorar as possíveis correspondências com unidades ou subunidades coletivas atuais na região. Em suma, está também fora de cogitação qualquer balanço do tipo "quantos grupos sobreviveram". Não obstante, dois comentários podem ser elaborados. Em primeiro lugar, como sugere Bruzzi da Silva (1977, p. 30ss.), é bem provável 
que entre os termos arrolados encontrem-se nomes de sibs ou clãs, a unidade básica da organização social rionegrina, que em conjuntos de tamanhos variáveis constituem o esqueleto interno dos grupos exogâmicos patrilineares contemporâneos. Nesse sentido, pode-se conjecturar que a profusão histórica de designações coletivas não deixa de guardar alguma coerência com sua quantidade contemporânea, ainda que buscar pela correlação entre as duas séries não faça sentido algum - afinal quantos clãs seriam possíveis contar entre os mais de 20 grupos atuais? Eis aí um cálculo quase impossível, e certamente inexato em qualquer tentativa de estimá-lo.

Em segundo lugar, e em sentido oposto a esse primeiro comentário, o conjunto geral de termos presentes nas várias listas apresenta, como apontado no início, um pequeno conjunto de cinco categorias que historicamente vieram a se tornar etnônimos: Baré, Uaupés, Baniwa, Warequena e Maku, termos que aparecem já listas do século XVIII. As listas do século XIX apresentarão outros nove termos conhecidos hoje como etnônimos: Tukano, Dessana, Tariana, Cubeo, Wanana, Pira-Tapuya, Miriti-Tapuia, Arapasso e Makuna. Em conjunto (cinco + nove), essa série forma, com poucos acréscimos, a paleta etnonímica que veio a ser fixada para a região pelos naturalistas de fins do século XIX, como Wallace, Stradelli e Coudreau, e pelos primeiros etnógrafos do começo do século XX, como Koch-Grunberg, Nimuendaju, Goldman e Bruzzi. Mas o ponto é que, principalmente quanto aos primeiros cinco, e em alguma medida para os outros nove, parece que esses (atuais) etnônimos corresponderiam a (antigas) categorias englobantes - ou mais genéricas? - a subsumir em seu interior várias outras daquelas com as quais se encontram arroladas nas listas do passado. Nesse sentido, e ainda que possa soar muito óbvio, das listas os séculos XVIII e XIX constam termos que se referem a coletivos em diferentes escalas. Podem, por um lado, expressar fenômenos moleculares de fissão, ou atomização, de unidades em escala local, como também fenômenos molares de fusão, ou englobamento, de unidades em escala regional ou sub-regional. Escravização e descimento certamente influenciaram essa dinâmica, mas em hipótese alguma podemos estar seguros de que a tenham determinado totalmente. 
Pois, tomando-se a primeira série de cinco etnônimos, é possível, a meu ver, ir um pouco além dos comentários anteriores, já que esses termos não parecem se definir somente pelo fato de serem inclusivos. O exame histórico de sua cristalização em etnônimos sugere, com efeito, que sua continuidade ou permanência (ou sua própria existência?) se deve também às relações contrastivas que mantêm entre si. Esse ponto pode ser bem ilustrado a partir de uma oposição entre o termo "baré", por um lado, e os termos "uaupes", "baniwa", warekena" e "maku", por outro. Tal oposição refere-se a uma classificação geral que cobre todos os povos da região segundo sua localização ao longo dos principais rios da bacia dos formadores do rio Negro. Ao passo que os chamados baré situam-se ao longo do próprio rio Negro, os termos uaupes, baniwa e warekena referem-se a grupos até hoje situados nos rios Uaupés (Caiari), Içana e Xié, respectivamente. Já o termo Maku refere-se aos grupos caçadores-coletores afastados das margens dos rios e que levam uma vida seminômade por entre os interflúvios ao sul das calhas dos rios Uaupés e Negro. Em suma, se somamos a área de cobertura geográfica dessas cinco categorias no presente teremos praticamente a extensão global da parte brasileira da grande região do noroeste amazônico. Há aqui dois detalhes importantes. Ao longo do século XX, os termos baré e uaupes irão desaparecer e reaparecer: os grupos chamados baré passam progressivamente a engrossar o contingente populacional "civilizado" da região, dispensando com o passar dos anos esse termo regional que marcava sua origem indígena. É somente nos anos de 1990, já no contexto da luta pela demarcação das terras indígenas, que é retomado o uso do termo baré como etnônimo. Já no caso do termo uaupés, passará com o tempo a designar o rio que, ao longo dos séculos XVIII e XIX, era conhecido como Caiari. Seus habitantes, até então conhecidos genericamente como uaupés, passarão ao longo do século XX a ser referidos com os outros etnônimos mencionados há pouco (a lista dos nove), e que até hoje designam os povos da família linguística tukano oriental.

As distintas trajetórias dos termos baré e uaupes deixam, a meu ver, absolutamente claro aquilo que os exames das fontes históricas já apontavam, isto é, trata-se de categorias genéricas, ao menos no uso 
de que tais categorias foram objeto no passado. Mas essas trajetórias reforçam também a ideia de que há - ou houve - entre esses termos uma dinâmica contrastiva. Segundo Nimuendaju ([1927]1982), evidências históricas e linguísticas permitem classificar todos os povos que habitavam ao longo do curso do rio Negro como pertencentes à família Arawak, sendo as línguas baré e manáo majoritárias. De acordo com o único estudo linguístico existente para o baré, essa língua seria, com efeito, a de maior alcance entre o médio rio Negro e os rios Cassiquiari e Orinoco, já na Venezuela, ainda no século XIX e início do século XX. Na década de 1990, contava-se não mais que algumas dezenas de falantes dessa língua na Venezuela, e nem mesmo uma dezena em lado brasileiro (Aikenvald, 1995). Em sua grande maioria, os Baré, que nesse momento retomavam sua identidade indígena, eram falantes há várias gerações de uma língua de colonização, o nhengatu, que, assim, passava a constituir uma das marcas de sua reindianização ${ }^{8}$.

Parece bem plausível, portanto, que no relativamente extenso período dos descimentos e aldeamentos que se seguiu ao fim do tráfico de escravos, o termo baré passasse, progressivamente, a ser utilizado de modo mais abrangente, uma vez que, como enfatiza Wright (1992), essa é uma tendência já verificada nas primeiras fontes escritas para o rio Negro. Há inclusive uma afirmação de Alfred Wallace (apud Aikenvald, 1995) sobre esse ponto, de acordo com a qual baré, já em meados do século, englobaria vários grupos diferentes. É possível supor também que, nesse processo, muitos grupos tenham progressivamente deixado de ser referidos (e a referir-se a si mesmos?) a partir de designações particulares e passado a ser incorporados na camada considerada civilizada da região9 . Designados como tapuias, ou baré, a marca distintiva desse contingente era o fato de já serem então considerados "civilizados": já falavam a língua geral (nhengatu) e viviam nos sítios e arraiais implantados no rio Negro, envolvidos na economia do extrativismo - mais tarde da borracha - e na organização anual das festas de santo. Mantinham dívidas com patrões e comerciantes como também eram os responsáveis por recrutar a mão de obra indígena dos altos rios (Andrello, 2006). A ambiguidade dessa posição é coerente com a incerteza que envolve a tradução do termo. De acordo com Aikenvald 
(1995, p. 3), haveria duas acepções praticamente opostas para o termo baré: se por um lado seria "branco", por outro seria "escravo" - ver também Pérez (1987), o que franquearia àqueles assim classificados o trânsito entre um polo e outro, isto é, da condição de gentios (objetos de resgate e escravização no XVIII) à condição de brancos (intermediários, ou sujeitos, nos descimentos dos índios das cabeceiras entre o XVIII e o XIX). Ou seja, apesar do risco de sobreinterpretação que corre-se aqui, talvez não seja absurdo pensar que baré designe sobretudo essa passagem. Do ponto de vista baré propriamente dito, nada pode se dizer, mesmo porque talvez não haja um "baré propriamente dito". Nesse sentido, talvez corresponda mais propriamente a uma condição eminentemente variável, e cuja definiçãa envolveria sempre um ponto de vista exterior aos assim designados.

Se assim for, a dinâmica contrastiva que, ao mesmo tempo, envolve e é interna ao termo baré apontaria para o fato de que as demais categorias que lhe são opostas devem igualmente corresponder a possibilidades de classificação dos assim nomeados, isto é, os uaupés, warekena, baniwa e maku. Quando baré aparece como a figura do nativo civilizado, essas outras seriam possivelmente o contrário, isto é, a dos gentios ainda não reduzidos ou descidos. Pois, de acordo com Koch-Grunberg ([1909/10]1995, Tomo I, p. 223), "uaupes" seria a designação que antigos habitantes arawak do rio Caiari (hoje Uaupés) vieram a atribuir a outros grupos que invadiram a região, vindos do sul ou sudoeste, como os Tukano e Cubeo, uma hipótese cuja verificação exigiria estudos linguísticos aprofundados. Por outro lado, não há o que objetar quanto à conotação que envolvia o termo por ocasião de sua viagem. Tratava-se, segundo o etnólogo alemão, de uma categoria pejorativa, que não era bem aceita por qualquer nativo da região, tukano ou arawak falantes ${ }^{10}$. A mesma coisa parece se passar na relação do termo baré com os demais. Particularmente com relação àqueles chamados warekena, considerados selvagens e canibais, baré é sinônimo de gente civilizada e trabalhadora, o mesmo se passando com relação aos beligerantes manáos (Koch-Grunberg, 1911 apud Aikenvald, 1995). Com relação aos chamados maku, esse tipo de oposição é ainda mais saliente, pois se trata de termo até hoje usado explicitamente para se 
referir aos bandos itinerantes de caçadores-coletores, alguns deles até muito pouco tempo atrás endividados com patrões baré de São Gabriel da Cachoeira na extração de fibra de piaçava. Quanto ao termo baniwa, o caso parece ser um tanto distinto. "Irmão mais novo", "conhecedores da pajelança", "trabalhadores fiéis" são expressões que um homem baré pode lançar mão para falar dos Baniwa do rio Içana hoje em dia. Estes, por sua vez, ainda que tacitamente possam aceitar tais adjetivos, não são em geral capazes de precisar o significado do termo baniwa. Baniba, caniba, talvez "canibal" conjecturam às vezes, sem deixar de aceitar a alcunha.

Em suma, parece fora de questão que, como categorias genéricas, baré, uaupés, warekena, baniwa e maku operam desde há muito tempo como marcadores da sub-região (bacia) de origem de pessoas e coletivos. Aparecem assim como índices de distintas condições, pautados por uma oposição global entre aqueles há mais tempo impactados pela colonização - os baré - e os demais povos estabelecidos pelos rios Uaupés, Içana e Xié - uaupés, baniwa e warekena. Em uma primeira avaliação, seria possível dizer que tal classificação geral é coerente com os processos históricos de escravização e descimento dos índios dos altos rios. Nesse caso, os baré são aqueles que historicamente vieram muitas vezes a ocupar a posição de intermediários nesses processos, tendo adotado progressivamente a língua geral, o idioma dos brancos civilizados $^{11}$, mas certamente podendo se comunicar com os grupos arawak-falantes de rio acima.

Como já assinalado, o termo uaupés veio a cair em desuso, ao contrário de baniwa e warekena, que designam até hoje os grupos arawak do Içana e Xié. O termo uaupés foi cedendo lugar com os passar do tempo a outras designações que passaram a ser aplicadas aos grupos falantes da língua tukano oriental. E ao contrário do que se passa nos rios Içana e Xié, onde muitos grupos deixaram suas línguas arawak em favor da língua geral, no rio Uaupés é o tukano que está há alguns anos se tornando a língua franca. Talvez isso indique que as relações entre os moradores do rio Negro e os grupos de rio acima apresentem nuances de acordo com essas aproximações e distâncias linguísticas. Ainda que tal balanço exija pesquisas aprofundadas em várias partes 
da região, é possível, a meu ver, sugerir uma diferença nas relações vigentes entre, por um lado, grupos arawak falantes situados ao longo dos rios Negro, Içana e Xié, e, por outro, entre os arawak do rio Negro e os tukano falantes do Uaupés. O desuso do termo uaupés em contraste com a permanência dos termos baniwa e warekena talvez seja um sintoma disso: as relações assimétricas entre o baixo rio e o alto rio, à jusante e à montante, os baré e as demais gentes das cabeceiras parecem tacitamente aceitas no interior do conjunto de povos arawak, mas negadas no contexto das relações com os povos de fala tukano. Uma fronteira linguística viria, portanto, determinar, ao menos em parte, o formato da paleta etnonímica que veio a se consolidar no noroeste amazônico.

Em suma, categorias mais genéricas permaneceram em certas partes da região, mas cederam lugar em outras partes para outras menos genéricas. Essa é a razão pela qual, a meu ver, se verifica uma série de imprecisões na aplicação de noções como as de clã, fratria, grupos exógamos e/ou linguísticos e tribo na etnografia regional. Onde exatamente situá-las? Qual a ordem de grandeza atribuir a cada uma delas? A frase em epígrafe, de autoria de um dos primeiros etnógrafos da região (Sorensen, 1967), aponta para esse dilema, pois sugere a inexistência de noções análogas nas línguas locais, enfatizando por outro lado, e, sobretudo, a proliferação de nomes próprios associados a diferentes trechos dos rios da região, à montante e à jusante. Esse ponto é ainda endossado por Jean Jackson (1983, p. 72) e Christine HughJones (1979, p. 26), como o demonstra uma afirmação da segunda enfaticamente reiterada pela primeira: "a identidade de um clã é tão intimamente relacionada a seu nome que, em certo sentido, o nome é o clã". Como apontam as autoras, não haveria um conceito nativo rígido o suficiente para definir tais unidades e suas fronteiras. Na língua tukano, elas são chamados simplesmente de kurupa, "grupo", um termo que pode ser aplicado em contextos e escalas muito diferentes, o que demonstra que sua especificação é essencialmente problemática, no sentido de se tratar sempre de um problema a equacionar ${ }^{12}$.

Quer se dizer com isso que, aparentemente ao longo de todo o rio Negro, tão complexo quanto definir o que é um grupo seria lidar 
com os modos simultâneos e, muitas vezes antagônicos, de recortá-los e dotá-los de visibilidade; nos termos propostos por Wagner (2010), de como elicitá-los. No contexto Melanésio tratado por esse autor, os nomes postos em cena no processo de elicitação de unidades sociais constituem um modo de criatividade vinculado às distinções promovidas no contexto da troca de riquezas e mulheres - uma mulher recebida implica uma compensação a seus parentes com machados, porcos ou conchas por parte dos parentes de seu novo marido. Ao compensar as habilidades produtivas e reprodutivas femininas com os instrumentos da criatividade masculina, a carne que multiplica o esperma e as conchas que "criam a imagem masculina assertiva" (Wagner, 2010, p. 248), povos como os Daribi fazem clãs ou comunidades aparecerem como, nas palavras do autor, "associações não-intencionais", isto é, como o exato oposto das nossas formas ocidentais, "[...] em que as pessoas formam grupos por meio da participação deliberada" (Wagner, 2010, p. 249). É nesse sentido que o que pode parecer uma "socialidade permanente" corresponderia a "um contexto associativo ad hoc," marcado caso a caso pela separação entre os que dão a carne e aqueles que a comem ou compartilham. Desse modo, todo ato de troca fundamenta-se sobre, bem como estabelece, um contraste entre feminino e masculino, mas que jamais gera uma hierarquia rígida entre esferas de inclusão, de modo que mesmo unidades que compartilham a carne podem passar a trocar internamente e, assim, reproduzir contextualmente novas distinções do mesmo tipo - i.e. fractalidade. Nesse tipo de situação, grupos seriam criados, sobretudo, como um tipo de contexto geral para a expressão de alguém. São, portanto, "não-intencionais" no sentido de que emergem para outra finalidade que não a produção de uma corporação permanente, isto é, de uma "fusão ostensiva de indivíduos em um único corpo social" - ver também Wagner (2011). Vale, portanto, reter a ideia de que grupos são criados para a "expressão de alguém".

Nessa direção, Hugh-Jones (2015) já sugeriu que, no Uaupés e no rio Negro de modo geral, os vários níveis daquilo que usualmente se chama de organização social consistiriam em "expansões-contrações da mesma pessoa fractal". Isto é, do indivíduo ao grupo exogâmico, 
passando pelo segmento de clã e pelo próprio clã, teríamos uma série de níveis encaixados entre si, e, de modo importante, homólogos do ponto de vista das relações que implicam. Também aqui S. Hugh-Jones está se valendo do conceito "pessoa fractal" proposto por Wagner (Hugh-Jones, 2015), segundo o qual, pessoas, linhagens ou clãs correspondem a seções arbitrárias no quadro de um mesmo encadeamento genealógico-reprodutivo, ou seja, projeções fractais em maior ou menor escala. De modo importante, o principal exemplo de Wagner para ilustrar o conceito diz respeito aos nomes e à nominação, que, no caso melanésio, são ao mesmo tempo individuais e coletivos, e, mais do que isso, são o que realmente importa, é o que ganha ou perde proeminência em contextos rituais, como as trocas kula ou moka - i.e., é o que mobiliza aqueles que personificam poder naquela região (big-men, great-men, chiefs).

Diante de tudo isso, é possível aventar, a meu ver, que os processos de englobamento e de fragmentação e os nomes que suscitaram, tão frequentemente apontados na etnografia do noroeste amazônico, estão longe de haverem constituído fenômenos de distribuição homogênea pela região. Minha sugestão é que a série de etnônimos que veio a se consolidar a partir de fins do século XIX na região resulta, ao menos em parte, de uma dinâmica de designações e contradesignações projetadas em escala regional. A meu ver, aqui também grupos vieram a ser criados para a expressão de alguém, mas, diferentemente do caso melanésio, o código empregado não foi o de gênero, do masculino e feminino, mas o da montante e da jusante, o qual parece corresponder a um gradiente cujos polos extremos são as posições de humanidade e não humanidade. Um código, em suma, bastante oportuno para os fins coloniais, cuja empresa seria irrealizável sem os expedientes da escravização e dos descimentos.

No que se segue, veremos, no entanto, que a ressonância entre o código local e o código colonial é apenas aparente. Pois as relações assimétricas que implicam são de ordens diferentes. O caso dos povos tukano, e a multiplicidade de nomes que veio a ensejar, sugere um movimento de contradesignação face à designação unitária e majoritária que os Baré lhes haviam reservado - Uaupés. Movimento que, 
no entanto, não se constitui como um obstáculo intransponível para a ocupação de posições à jusante. Como se verá, alguns daqueles outrora chamados Uaupés viriam a vislumbrar como que um salto por sobre a condição baré, em um processo no qual, afetados pelas contingências da história, puderam imaginar para si mesmos aquela transformação sempre incompleta em civilizados, em brancos, da qual os próprios Baré já davam testemunho. Contradesignações, contra-hierarquia; passemos aos povos tukano.

\section{Do Genérico ao Particular e Vice-Versa}

Incluídos na categoria uaupés possivelmente por muito tempo, todo um conjunto de povos falantes das línguas tukano seria, como se viu, gente das cabeceiras de um ponto de vista baré. Porém, de seu próprio ponto de vista, a verdadeira gente das cabeceiras são os grupos localizados ainda mais acima de seu território - ou seja, os Barasana, Tatuyo, Carapanã e outros, que se localizam na região do Uaupés colombiano. Precisamente por esse motivo, somos levados a pensar em termos de um gradiente de personitude decrescente, que se estende entre os seguintes polos: da jusante à montante, de leste a oeste, do lago de leite à beira do mundo - pontos extremos do mundo descrito nas narrativas míticas - com gente como os Tukano, Desana, Tariana, Cubeo, Wanana, Pira-Tapuia, Tuyuka e Arapasso situando-se em uma zona intermediária. Esses são enfim alguns dos termos que passaram a figurar nas listas do século XIX e progressivamente eclipsar a categoria uaupés.

Mas alguns desses termos sugerem igualmente designações genéricas. Além dos Tukano ${ }^{13}$, que se explora em detalhes a seguir, esse é muito provavelmente o caso de outros três nomes da série anterior, como Desana, Tariano e Cubeo, que, ao contrário dos demais, não correspondem à autodesignações. Além de sua origem desconhecida e de vários indícios de se referirem de conjuntos compósitos, esses nomes possuem significado desconhecido mesmo para aqueles que hoje normalmente se incluem nessas "etnias". Possivelmente, isso se deve ao fato de os três termos se associarem a processos históricos de fusão envolvendo deslocamentos de coletivos oriundos da do rio 
Içana em direção ao rio Uaupés, na região do alto montante - onde os cursos de ambos se aproximam, permitindo a passagem de uma bacia a outra com relativa facilidade. Trata-se, com efeito, de deslocamentos de frações do grande conjunto arawak da porção norte da região que vieram a se integrar ao contexto tukano do Uaupés, situado mais ao sul. Nesse sentido, é notável que os termos cubeo, desana e tariano já constem das listas de etnônimos do século XVIII. Silvia Vidal (1999) sugere que se referem a grupos integrantes das chamadas "confederações mutiétnicas arawak" da primeira metade do século XVIII, as quais haveriam sido desmanteladas até o final desse século com o avanço da colonização portuguesa pelo rio Negro. Supõe-se com isso que haviam se refugiado a montante. Irving Goldman (2004) aponta que o grande contingente Cubeo atual do alto Uaupés tenha sido formado pela fusão de parte desses contingentes arawak oriundos do Içana com grupos tukano do Uaupés, ao passo que há indicações de que alguns dos clãs Desana seriam igualmente de origem arawak (comunicação pessoal de Dominique Buchillet).

A reforçar esta última hipótese, ressalte-se que os Desana não devem idealmente trocar esposas com os Tariano, que os consideram irmãos. Ora, os Tariano, por sua vez, são o caso mais emblemático desses possíveis processos de "tukanização" de povos arawak: ainda que em sua maioria sejam hoje falantes da língua tukano, resta até o presente um clã de baixa hierarquia falante de sua língua arawak original. Com esse clã, Alexandra Aikenvald realizou um aprofundado estudo linguístico, tendo inclusive produzido um dicionário dessa língua potencialmente em desaparição. Nesse dicionário, o próprio termo tariano aparece como "talia", que é traduzido como um tipo de peixe aracu (Aikenvald, 2001). Segundo os próprios Tariano, cuja autodesignação vem a ser Ennu Ianáperi (língua tariano, ou Bipó porã em tukano, em ambos os casos "Filhos do Trovão"), o uso do termo tália deve-se ao fato de que os Tariano se constituem como um grupo muito variado, exatamente como essa espécie de aracu, que possuiria muitos tipos internos. A analogia, portanto, relaciona-se à diversidade interna, sugerindo que os Tariano, tal como os Desana e Cubeo, corresponderiam a uma composição de coletivos sucessivamente incor- 
porados sob a mesma alcunha, os quais correspondem atualmente a seus mais de 20 clãs. Ao contrário dos Desana e Cubeo, no entanto, seu processo de tukanização é específico e incompleto, por assim dizer: até hoje afirmam suas origens no Içana, ao lado dos Baniwa e outros povos arawak, não obstante sua proeminência em tempos passados no rio Uaupés - em função de uma possível e peculiar relação que entreteceram com os Baré no passado (cf. nota 11).

Ou seja, tal como se pode sugerir a inserção das categorias baré, baniwa e warekena em um mesmo continuum jusante-montante no eixo formado pelos rios Negro, Içana e Xié, os Tariano parecem ter ocupado, até certo momento, uma posição equivalente à dos Baniwa e Warekena no eixo formado pelos rios Negro e Uaupés, constituindose como os "chefes dos Uaupés", de acordo com a pena de Stradelli (Andrello, 2006). Mas aí, como salientamos, representavam, como em certa medida até hoje, um enclave arawak entre os povos de fala tukano, os quais parecem jamais ter se ajustado à posição de uaupés a que foram relegados. E é entre estes, mais especificamente entre os Tukano propriamente ditos, que esse dispositivo em forma de gradiente pode ser apreendido com maior precisão. A meu ver, encontramos também entre eles a mesma estrutura compósita que nos deparamos em diferentes escalas, e que, nesse caso, registra com grande nitidez as marcas características de seu processo de constituição. Eis a hipótese que estou sugerindo: os Tukano, por motivos ainda a elucidar, se nos apresentam como uma espécie de síntese em escala manejável dos processos de formação de grupos no noroeste amazônico. Vejamos.

Para os Tukano, as posições contrastivas baré e uaupés correspondem, grosso modo, às de "branco" e "índio", ainda que, de seu ponto de vista, os baré não sejam exatamente brancos - mas tampouco eles seriam exatamente índios! Em sua própria língua, essas posições diametrais são traduzidas com as expressões pekâsã e po'teríkãharã. O primeiro termo é uma forma abreviada da expressão pekâ-masa, "gente-espingarda" e evocação direta do evento mítico de origem dos brancos ${ }^{14}$. Já o termo po'teríkãharã refere-se genericamente aos indígenas da região, e se traduz como "aqueles que são das cabeceiras", tendo sido usada desde o tempo dos primeiros missionários que se fixaram 
no Uaupés com uma conotação de "não-civilizado". A conotação depreciativa do termo é, com efeito, confirmada por outros atributos a ele associados, como "comedores de tapuru", palavra da língua geral que engloba vários tipos de larvas, que se reproduzem em várias espécies de árvores, em particular nas palmeiras. Essa expressão é usada pelos Tukano para designar, precisamente, os po'teríkãharã, "a gente das cabeceiras", como ba'tî íia-masa, "a gente do tapuru", que se refere àqueles que vivem de comer tapurus. Gente assim é considerada "sem juízo" (tíomasítirã), "sem planos", "que vivem como bêbados", e que comem tapurus por não terem sua própria comida. Aí está a razão pela qual os Tukano não se vêem enquanto "gente das cabeceiras", como uaupés. Entre os dois polos, afirmam com certa frequência uma terceira posição, em certo sentido intermediário e internamente diversificado, a que dão o nome de pamt̂rì-masa, isto é, "gente de transformação".

Como as outras duas, essa categoria é igualmente englobante, pois inclui todos os aqueles cujos ancestrais foram transportados no bojo da cobra-canoa desde o Lago de Leite. A saga de uma anaconda ancestral que conduz os ancestrais dos povos do Uaupés até a cachoeira de Ipanoré, no médio curso desse rio, é um motivo bastante conhecido e que toma parte em praticamente todas as e versões conhecidas do mito de origem da humanidade na concepção tukano. Segundo o relato de que se dispõe, os tripulantes da embarcação, ou aqueles que conformavam o corpo dessa cobra de transformação ainda em forma

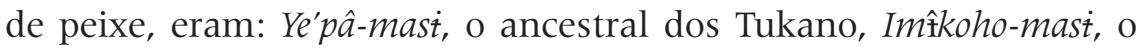
ancestral dos Desana, Pĩrô-masí, o ancestral dos Pira-Tapuia, Kõreâgí, o ancestral dos Arapasso, Di'ikãhágí, o ancestral dos Tuyuka, Bekagí, o ancestral dos Baniwa, Barêgí, o ancestral dos Baré, Pétârĩ, o ancestral dos Petarã, e Pekâs̃̃, o ancestral dos brancos ${ }^{15}$. Note-se que mesmo os Baniwa, Baré e brancos são incluídos entre os tripulantes da canoa de transformação, mas não irão se fixar no rio Uaupés. Os Baniwa são deixados no Içana anteriormente; e os Baré e os brancos, embora tenham saído em forma humana por meio dos buracos existentes nas lajes de Ipanoré como os demais, se deslocam, em seguida, no sentido contrário - a transformação a que tudo isso se refere diz respeito a uma metamorfose que ocorre na passagem do meio aquático ao meio 
terrestre, isto é, ao despirem-se de suas roupas de peixes, essa gente do começo irá se mostrar entre si em forma humana. Ao passo que os ancestrais dos povos tukano se dirigiram rio acima em busca de seus territórios, Barêgì e $P e^{\prime} t a ̂ r \tilde{r}$, que vieram a dar origem aos Coevana ${ }^{16}$ e Baré, bem como Pekâs̃̃, o branco, seguem rio abaixo. Os primeiros vão se fixar no rio Negro, o segundo no Lago de Leite e alhures, por outros continentes - o Lago de Leite é a baía da Guanabara. Essa é a gênese da história humana propriamente dita, no início da qual esse conjunto de diferenciações já aparece como um dado, sempre sujeito, porém, a novas transformações, como veremos.

Já os chamados po'teríkãharã, a "gente das cabeceiras", possuem um origem distinta, ainda que em algum grau conectada com a origem dos pamîrí-masa, a "gente de transformação". Segue uma explicação sobre esse ponto fornecida pelo senhor Gregório Soares, velho kumu (xamã-rezador) tukano de Iauaretê:

Como nós temos nosso surgimento no Pa'mîri-pee [o buraco da laje de Ipanoré], lá mesmo começou o respeito entre os grupos [ẽhopeósehe, "respeito, tratamento adequado entre as pessoas e grupos"]. Já esses grupos que surgiram aqui no Aracapá [cachoeira da foz do rio Papuri, que lança suas águas no Uaupés à altura de Iauretê], esses são po'teríkãhara. Como os yiarã, [salgados, grupo desconhecido], eêruria , [Eduria, nome de grupo sem tradução], pamoá [tatu, Tatuyo], bosoá [acutivaia, grupo desconhecido], wa'î-yãra, [peixe- ??, MiritiTapuia, mitteá [mosquito chamado carapanã, Karapanã], pãrêroa [desligados, descolados, Barasana e parte dos Makuna]. São grupos que apareceram mais para cima, nas cabeceiras, e surgiram através do ipadu [folha de coca torradas e pulverizadas, de uso ritual]. Na cachoeira de Aracapá há uma pedra que se chama paâtu-poâstika [de poâstise, "cheiro diferente"], pedra do cheiro de ipadu queimado. Por isso que esses grupos são comedores de ipadu. Foi ali que esses grupos surgiram. Nessa cachoeira, estão as casas sagradas desses grupos, lá se encontra sua força vital [eheri-porã, respiração]. Esses grupos têm a capacidade de fazer malefícios através de uma picada de cobra invisível, a mais venenosa delas. Quando os velhos kumua [xamãs-rezadores] tentavam atacar esses grupos para se proteger, eles tinham que procurar sua 
força de vida nessa cachoeira de Aracapá. Esses grupos não fizeram parte da viagem da canoa dos ancestrais. Eles são considerados os avôs dos Pa'mîrí-masa. Ao contrários deles, nossos ancestrais não comiam ipadu, mas farinha de milho e de tapioca. [...] Nós não fazemos parte dos po'teríkãhara, foram os missionários que aplicaram essa palavra para todos os grupos da região. Os antigos desconsideravam os po'teríkãhara, diziam que eles eram inferiores. (Gregório Soares, Iauaretê, junho/2002).

O relato é significativo em vários aspectos. Em primeiro lugar, opera uma clara distinção entre a gente de transformação que surge em Ipanoré e aqueles que surgem mais acima, já na foz do rio Papuri. Em segundo lugar, aponta os nomes de sete outros grupos da família linguística tukano atualmente situados em lado colombiano, mais especificamente no rio Pirá-Paraná, já na bacia do Apapóris, dos quais há, inclusive, alguns não registrados pela etnografia disponível, como os chamados yiarã, bosoá, wa'î-yãra - os demais, Eduria, Tatuyo, Karapanã, Barasana e Makuna, são quase todos grupos estudados em monografias hoje clássicas - ver Bidou (1976), Christine HughJones (1979), Stephen Hugh-Jones (1979), Arhem (1981), Correa $(1996)^{17}$. Por fim, o relato estabelece uma relação bem específica de parentesco entre a gente de transformação e a gente das cabeceiras: os primeiros são netos, os segundos são seus avôs. Voltaremos a essa forma de tratamento a seguir, mas é preciso registrar que ao falar em avós, fala-se em gente inferior, no sentido de "os que vêm depois", o idioma privilegiado de relações hierarquizadas no Uaupés (Andrello, 2015). Nesse sentido, não é gente com quem se troca esposas, o que sugere a conformação entre os povos tukano de duas esferas distintas de intercâmbios matrimoniais, uma interna ao conjunto pamt̂̀ri-masa, a gente de transformação, e a outra que articula todos esses outros povos considerados pelos primeiros como das cabeceiras. Distância social mediada tanto pela geografia quanto pelo tempo - surgiram mais tardiamente e fixaram-se a montante - mas no relato dois outros itens vêm marcar a distinção: nas cabeceiras estão os grupos que consomem ipadu em grande intensidade, bem como são os detentores dos malefícios xamânicos mais potentes - a picada da cobra invisível - ao que os xamãs da gente de transformação podem fazer 
frente interferindo nas fontes de sua vitalidade, alocada na cachoeira de Aracapá. Comedores de tapuru são, portanto, comedores de ipadu e, assim, feiticeiros em potencial.

Desse modo, delineia-se com um pouco mais de precisão o gradiente jusante-montante de que viemos tratando. No pólo das cabeceiras, a um xamanismo maléfico poderoso articula-se o consumo de ipadu e um hábito alimentar próprio àqueles que habitam rios pouco piscosos, os que são comedores de tapurus. Já rio abaixo, um xamanismo de proteção associar-se-ia a uma maior abundância de recursos materiais, fartura de peixe e acesso mais facilitado às mercadorias dos brancos. Aí estão os grupos maiores, que em seu processo de crescimento passariam paulatinamente a explorar novas áreas à jusante, e, assim, estabelecendo um leque maior de alianças. Em hipótese alguma, pode-se afirmar que esses parâmetros correspondam a uma prática em operação de ponta a ponta no que seria um sistema estruturado de relações sociais; ao invés disso minha sugestão é a de que se trata de um modelo ao qual as pessoas em geral recorrem para refletir acerca de sua posição e balizar as transformações experimentadas em suas próprias vidas e na de seus antepassados, que ocorrem precisamente ao longo do gradiente delimitado por essas duas situações extremas. Em suma, duas imagens que correspondem a contextos marcados por uma maior ou menor intensidade de relações entre, rio acima, humanos e não humanos, e, rio abaixo, de humanos entre si. A trajetória pós-mítica dos Tukano propriamente ditos, marcada pela dispersão progressiva de seus clãs desde um território original - o igarapé Turi, afluente do rio Papuri - reproduz, agora em uma escala ainda mais reduzida, esse mesmo padrão. Na terra original, restam os membros do clã especializado no xamanismo, responsável por guardar as fontes do conhecimento e vitalidade do grupo como um todo; rio abaixo, chefes acompanhados de seus irmãos menores buscam novas áreas e relações com outros povos. Passemos então agora aos Tukano propriamente ditos.

Ainda que os Tukano aceitem essa alcunha, eles advertem frequentemente tratar-se de um apelido, agregando que seu nome verdadeiro é, em sua própria língua, Ye'pa-masa, "gente-terra", tal como 
já aponta a lista de termos internos para a gente de transformação arrolados anteriormente. Como designação externa, Tukano seria um epíteto atribuído por outros, de uso corrente, sobretudo, entre seus cunhados próximos, os Desana, Tariano, Pira-Tapuia e outros. Mais especificamente, trata-se de um apelido a eles atribuídos por seus cônjuges potenciais pertencentes a esses outros grupos. Segundo elas, esses homens que andam em bandos, sempre muito ávidos por comida e prontos a agarrá-las, se parecem com tucano, isto é, com a ave cujos hábitos ofereceriam uma perfeita comparação com os modos desses comilões mulherengos. Via de regra, os assim chamados Tukano afirmam que o apelido foi cunhado por mulheres desana, mas não é impossível que tenha sido rapidamente incorporado por mulheres de outros grupos, já que os Tukano vieram progressivamente ampliando seu leque de alianças - são hoje o maior grupo do Uaupés, cuja língua, como mencionamos, vai se tornando língua franca nessa área. Isso é um sinal de que se constituem também como um dos principais fornecedores de mulheres aos demais grupos do Uaupés, cujos filhos vieram progressivamente adotando a língua de suas mães - e assim a língua tukano vai se sobrepondo ao tariano, ao desana e assim por diante.

Em suma, não obstante o caráter jocoso do nome que já não há como recusar, a importância dos Tukano do rio Uaupés é inquestionável; o alcance de sua língua, a amplitude de sua dispersão territorial e seu sucesso demográfico são sinais inequívocos disso. Mas todos os assim chamados Tukano conformariam um grupo coincidente com a autodesignação Ye'pa-masa? Não é exatamente isso que se passa, pois há outros grupos autodesignados como Ye'pa-masa, (ou Ye'bamasa, igualmente traduzido como "gente-terra") localizados mais a oeste dos Tukano. Precisamente alguns daqueles considerados pelos Tukano como "gente das cabeceiras", como os Barasana e alguns dos clãs Makuna, chamam a si mesmo de "gente-terra" ou Ye'ba-masa. Esse dado, que será preciso explorar em maior profundidade em outra ocasião, já sugere que a condição tukano, por assim dizer, não é homogeneamente compartilhada por todos os que se autodesignam Ye'pa-masa. Seria talvez possível, com base no que já foi dito, sugerir que Tukano seriam os Ye'pa-masa que, situados entre os rios Tiquié, 
Papuri e Uaupés, vieram a ocupar posição de destaque no contexto de relações específicas que os liga aos Desana, Tariano, Pira-Tapuia e Tuyuka. De qualquer forma, a ocorrência do mesmo nome à montante e à jusante reforça a ideia de uma continuidade entre a gente das cabeceiras e a gente de transformação. Mas consideremos o conjunto Ye'pa-masa específico que viria a ganhar fama como Tukano.

Nesse contexto ocorrem imprecisões significativas, pois se há, por um lado, Ye'pa-masa não-Tukano na Colombia, há por outro, grupos ex-Maku na porção do médio Uaupés (Brasil) que vieram a se tornar Ye'pa-masa e, assim, Tukano, como também há grupos Ye'pa-masa que deixaram de ser Tukano ao baixar o rio, tornando-se Baré ou brancos. Vejamos, assim e em linhas gerais, a constituição interna do grupo hoje conhecido como Tukano.

Seguindo o esquema elaborado pelo tukano Arlindo Maia ${ }^{18}$, os Tukano corresponderiam a 36 clãs nomeados e agrupados em seis blocos distintos, encadeados hierarquicamente de acordo com papéis rituais: quatro clãs compõem o bloco dos "irmãos maiores" (chefes), 20 clãs compõem o bloco dos "irmãos menores" (guerreiros), um clã forma sozinho o bloco dos especialistas em encantações xamânicas e cantos; por fim, há dois blocos de servidores, "preparadores de cigarros", com cinco e sete clãs. Há alguma controvérsia quanto à ordem interna dos clãs nos blocos intermediários, casos em que não é incomum que as pessoas expressem dúvidas sobre a posição correta ou o nome verdadeiro de seu grupo. Por outro lado, parece haver consenso quanto ao fato de que o tema é objeto de conhecimento especializado, motivo pelo qual somente homens mais velhos e pertencentes a clãs de grande prestígio gozariam da prerrogativa de elencar tais grupos e sua ordem. Não obstante, em paralelo a esse tipo de reconhecimento aceita-se amplamente que cada clã guarda a memória acerca dos feitos e do nome de seu ancestral fundador, bem como dos eventos específicos da trajetória de seu grupo. A importância atribuída ao conhecimento especializado, combinada a certa garantia assegurada a cada clã quanto à elaboração de uma narrativa própria, enseja a constituição de um extenso campo de debates referente ao coletivo mais amplo conhecido como Tukano. Esse fator dá margem a frequentes 
contradições e a alegações corriqueiras acerca do caráter improcedente de pleitos quanto a posições hierárquicas e pertencimento a grupos. Definir a "situação existente" em um dado momento no interior do conjunto como um todo consiste, portanto, em uma tarefa complexa e, frequentemente, fadada a não atingir um quadro consensual, fixo e permanente (Hugh-Jones, 1979).

Porém, ainda que a ordem e a composição daquilo que se passa na região intermediária dessa escala, em geral mais extensa, tendam a flutuar, variando de acordo com a posição e o conhecimento daquele que fala, há, por outro lado, um alto grau de consenso quanto aos nomes dos clãs que figuram nas regiões superior e inferior da escala. Se o que se passa na zona intermediária dessa escala suscita frequentemente questionamentos, o que se passa em suas pontas superior e inferior não parece ser objeto de versões divergentes. Ao contrário, todos os Tukano são capazes de se lembrar de que o nome (Yuupuri) e, sobretudo, o apelido (Wa'ûro), de seu irmão maior ${ }^{19}$. Ao recordar esses nomes, costuma-se agregar que seus descendentes já não vivem na região, pois partiram há muito tempo para o leste, baixando pelos rios Uaupés, Negro e Amazonas. Trata-se de um episódio de importância geral para o conjunto dos clãs tukano, e cuja razão refere-se a um fratricídio que teve lugar em um afluente do rio Papuri, onde todos os clãs se concentravam em passado distante, antes do início de seu processo de dispersão. A desavença haveria ocorrido entre Wa'ûro, o mais velho, e seu irmão menor, Oyé. Aconteceu que seus respectivos grupos passaram com o tempo a crescer de maneira desigual, com a vantagem pendendo claramente em favor do caçula. A situação era insustentável, pois do ponto de vista do mais velho era exatamente o contrário que devia ocorrer. Em geral, é precisamente o crescimento diferencial dos clãs que desestabiliza as relações hierárquicas. Esse aspecto das relações agnáticas no Uaupés diz respeito a uma variável temporal constituinte daquele gradiente de personitude já sugerido, de acordo com o qual os clãs ou grupos maiores, i.e. "mais velhos", situam-se idealmente à jusante - chegaram antes - ao passo que os mais novos situam-se a montante, a "gente das cabeceiras" - encontraram seus territórios mais tarde, quando os primeiros já possuiriam filhos e 
netos, motivo pelo qual são considerados seus avós. Essa ordem só se mantém, no entanto, se não houver variação em termos de crescimento - crescer é descer na escala espacial, e subir na escala hierárquica/ temporal, isto é, ocupar espaços mais proeminentes ${ }^{20}$.

Em função do crescimento desigual, os irmãos duelaram, e o mais velho sucumbiu. Seus descendentes decidiram então descer, como que efetuando na geografia o que não foi possível na história. E, assim, contam em geral os Tukano, os descendentes de Wa'ûro tornaramse civilizados, indo de encontro aos brancos de rio abaixo. Ou seja, igualam os próprios Baré. Aliás, deixaram de se casar com mulheres desana, de quem haviam recebido o apelido tukano, pois irão passar a casar-se com as brancas ou baré. Assim, seus filhos já têm a pele clara e com pelos, já trabalham em escritórios com máquinas, em cidades como Belém, Rio de Janeiro e Brasília. Dizem que são realmente como brancos, embora não se esqueçam de seus nomes Ye'pâ-Masa. Mas, em todo caso, parece que já não se enquadram perfeitamente na categoria tukano, pois deixaram de se casar com mulheres de quem receberam esse apelido.

Além disso, na extremidade oposta àquela onde se situa Wa'ûro, isto é, nas últimas posições da escala hierárquica dos Tukano em geral, encontraremos cerca de 12 clãs acerca dos quais não há controvérsias quanto à sua baixa posição hierárquica. Uma parte de deles, segundo se conta, veio se incorporando paulatinamente aos Tukano, em um período mais tardio, isto é, após a partida de Wa'ûro e da dispersão tukano do Papuri em direção ao Tiquié, e ao baixo Uaupés. São grupos que se fixaram por largo tempo nas imediações da cachoeira de Ipanoré, onde a proto-humanidade desembarcou da cobra-canoa que a transportou desde o lago de leite, ao leste, tendo alcançado o território tukano no rio Papuri mais tardiamente ${ }^{21}$. Outros casos referem-se explicitamente a grupos Maku-Hupda da margem colombiana do Papuri, que após contato com missionários mofortianos foram paulatinamente saindo da floresta e adotando o modo de vida ribeirinho dos Tukano. Com o tempo, foram incorporados por estes, fazendo jus a uma condição propriamente tukano. Em suma, nas regiões limites, por assim dizer, do campo social tukano há gente ex-maku e gente que acedeu a uma 
condição baré. O que leva a pensar que as unidades intermediárias entre esses polos podem também mover-se no espaço e alterar-se no tempo, à medida que crescem ou decrescem, isto é, ao lograr alargar ou ver encolher seu próprio campo de ação no interior de um espaço contínuo.

A partir disso, seria possível assim dizer que o epíteto tukano refere-se a uma posição situada numa parcela específica no continuum jusante-montante. A meu ver, a existência de outros Yépâ-Masa rio acima que não chegaram a receber a alcunha, bem como a ocorrência de grupos ex-maku que vieram a adentrá-la, e, por fim, história de Wa'ûro, um Ye'pâ-Masa que veio a superá-la rio abaixo, por assim dizer, sugere exatamente isto: tukano constitui, como muitas outras, uma categoria compósita que se, por um lado, desenha os contornos imprecisos de uma condição socioespacial ou sociopolítica específica, por outro, apresenta-se como um meio de passagem em potencial, uma série de posições em variação contínua. Nessa série, aos movimentos espaciais de expansão ou de contração corresponde o movimento do tornar-se, do devir: Maku torna-se Tukano sem deixar de sê-lo assim como Tukano torna-se branco sem deixar de ser Yepâ-Masa. No mesmo movimento, avós são tios ou irmãos menores em potencial - em suma, um cromatismo generalizado (Deleuze; Guatari, 1995, p. 38). Mas há mais, pois esse tráfego entre categorias gerais implica ainda lidar com as imagens produzidas a partir de um ponto de vista externo aos sujeitos. Nesse sentido, se as velhas categorias como baré, baniwa, warekena ou uaupés correspondem a estimativas sobre si feitas por gente de rio acima ou rio abaixo, o epíteto tukano conforma-se desde o ponto de vista de esposas potenciais, irmãs dos cunhados desana. Uma diferença de escala associa-se, no caso dessas designações gerais, a uma diferença quanto ao tipo de alteridade que lhes dá origem: gente em outras posições na rede fluvial e gente de outro sexo. Em ambos os casos, o código alimentar entra em operação, pois no primeiro caso alega-se que o outro é outro porque come outra coisa (tapurus), no segundo come de outro modo (em excesso), o que parece indicar que o fenômeno constitui-se essencialmente como um problema de perspectiva (Viveiros de Castro, 1996; Lima, 1996), porém operando simultaneamente em diferentes escalas. 
Mas se o esforço todo consiste em transpor o limiar entre essas categorias genéricas e derrogatórias, que Calavia sugeriu em seu artigo neste dossiê chamar de "heterodesignações", o modo como isso é feito no Uaupés é complexo. Pois não se trata, ou não se trata apenas, de alçar-se a uma categoria melhor situada na rede - de uaupés ou tukano, ou baniwa e warekena, a baré, coisa que pode ser corriqueiramente registrada no rio Negro até os dias de hoje (Dias et al., 2006). Sob esse fato corrente, há, a meu ver, uma habilidade insuspeita, pois é preciso e, talvez de modo crucial, saber extrair-se da condição a ser superada guardando algo de si. Isto é, é preciso saber enunciar um ponto de vista próprio, mas que nesse caso não consiste na afirmação de um "nós" face a um "tu", que via de regra resulta em autodesignações do tipo "nós, gente" - transformação de um pronome em nome (ver novamente o artigo de Calavia neste volume). O que está em jogo nesse caso, como sugere o mesmo autor, não é uma sintaxe de pronomes, mas uma semântica de etnônimos (Calavia Sáez, 2002), o que, no caso do Uaupés, parece depender essencialmente da capacidade de apontar para uma designação alternativa aquela formulada por um interlocutor virtual; em suma, a capacidade de formular uma contradesignação à altura. Como fazê-lo?

A tarefa não é certamente simples, mas um de seus aspectos centrais é saber sair de si mesmo sem evanescer, sem simplesmente tomar a posição ocupada de antemão por outrem. Para tanto, é preciso, ao mesmo tempo, adotar e transbordar seu ponto de vista. Yupuli Wa'ûro, o tukano que partiu rio abaixo com seu pessoal, encarna esse esforço de maneira elíptica. Ele já não está mais lá a encabeçar os coletivos tukano atuais, pois se tornou branco em cidades como Belém e Rio de Janeiro. Conta-se que seus descendentes aparecem vez ou outra na região, ocupando aquelas posições mais destacadas entre os brancos, a de cirurgiões no hospital militar ou de pilotos das grandes aeronaves que abastecem os pelotões de fronteira. Sabe-se que podem falar a língua tukano, como alguns já o constataram em experiências quase xamânicas, em meio a bebedeiras nos bares noturnos de pequenas cidades da região. No dia seguinte, porém, se fazem de desentendidos e já não atendem quando indagados no léxico local. Suspeita-se que já 
não são Tukano e, tampouco, Baré, são brancos e Ye'pâ-masa, "genteterra", pois conta-se ainda que, embora vivam como brancos, não se esquecem de seus nomes originários, isto é, aquela série de nomes -posições que compõem o corpo cromático da cobra-canoa.

A esses, Calavia (neste volume) sugeriu chamar de "nomes intensivos", já que frequentemente oriundos da mitologia e que, superpostos a uma cosmologia perspectivista, guardam a propriedade de fazer aparecer um novo sujeito no discurso. No caso tukano, constituem precisamente o estoque de sete ou oito nomes "de espírito" (Hugh-Jones, 2002 ) associados a pontos específicos da geografia fluvial, e atribuídos xamanicamente a recém-nascidos. Não são vocativos, mas proferidos em situações rituais pra designar coletivos inteiros, isto é, aqueles que compõem a relação de clãs mencionada mais acima. Mas como vimos, clãs são 36 e nomes sete ou oito. Com efeito, no tempo humano propriamente dito esse reduzido, e assim intensivo, conjunto se desdobra em extensão, repetindo nomes muitas vezes, mas garantindo a identificação de distintos coletivos por meio de sua associação a apelidos particulares (cf. nota 18). As narrativas referentes ao tempo pós-mítico dedicam-se a elencar a fixação dos primeiros portadores desses nomes e seus coletivos no alto montante e a afirmar a alocação do branco à jusante. A história de Yupuli Wa'ûro não aponta, portanto, apenas para um movimento de igualar-se ou tornar-se baré, mas vai além disso, conectando os poderes do extremo montante aos do extremo jusante. Assim, ao se basear, sobretudo, na intensificação dos descimentos, a colonização do rio Negro talvez não tenha produzido apenas aquela gente misturada, ou mestiça, das povoações de rio abaixo. Mesmo entre seus moradores, frequentemente chamados de "tapuias", "ladinos", ou baré, é bem possível que outras histórias como a de Wa'ûro tenham sido cogitadas. Pois a eles certamente terá ocorrido o mesmo tipo de pergunta feita por Manuela Carneiro da Cunha (1998, p. 18) em um artigo sobre xamanismo e tradução: "[...] como ter um ponto de vista local sobre um processo que nos ultrapassa, do qual não se controlam nem as causas nem os efeitos?" A resposta mais plausível encontrada pela autora estaria justamente na convergência entre o que é "mais local" e o que é "mais global". Caberia àqueles que se encontram nos lugares mais remotos efetuar tal operação e propor inovações. 
Mas esse tipo de fenômeno talvez não seja só uma resposta à colonização e à chegada do homem branco. A história do Tukano que se torna branco sem deixar de ser ele próprio, talvez seja mais um exemplo daquela "ontologia complexa e sobredeterminada" que Eduardo Viveiros de Castro (2011) discerniu nos textos clássicos de Mauss sobre magia e troca. Os dois fenômenos condensam traços contraditórios, como ceticismo e crença, ou generosidade e agressividade - no caso do primeiro, se o mágico não puder acreditar em sua própria magia, não poderá, contudo, duvidar da magia de outros. Daí a máxima retirada dos episódios nos quais um mágico retira um dardo invisível do corpo do paciente: "[...] a flecha que uns não veem partir, outros veem chegar". Os pilotos e os cirurgiões falantes do tukano são como essas flechas, que hoje retornam à região. O movimento que os origina é, supostamente, a partida de Wa'ûro, que, lembre-se, mediu forças com o irmão que ameaçava sua posição de primogenitura. Parecia a todos que o grupo do caçula tornava-se mais e mais proeminente, o que afetava de modo irremediável o mais velho, em um processo no qual o ponto de vista do outro vinha definir o significado de suas ações para ele próprio - haveria, assim, que descer o rio. Ponto de vista sobre ponto de vista, designações e contradesignações, que em casos limite como esse leva ao movimento rio abaixo e à separação. Mas esse é um caso limite, precisamente, e se é para continuar falando em hierarquia entre os sempre incontáveis grupos do rio Negro será preciso verificar se não se trata, como na magia e na dádiva, de multiplicidade intencional, de síntese disjuntiva (Viveiros de Castro, 2011, p. 141).

\section{Considerações Finais}

Diante de todas as especulações realizadas ao longo deste artigo, uma sugestão que os Tukano permitiriam formular e que talvez seja válida para os demais casos exemplificados ao longo do artigo, seria a de que se tratam todos de grupos que não coincidem a si mesmos, pois uma parcela sua pode sempre estar lhes escapando, como também uma parcela nova pode sempre estar emergindo ou lhes aderindo. Outras podem ainda manter-se ou serem mantidas sempre a distância. Nomes e categorias genéricas parecem, entre outras coisas, fornecer 
as chaves para descrever tais processos. Mas essa situação talvez não seja inteiramente específica ao noroeste amazônico. Alguns de seus aspectos parecem marcar contextos muito variados entre si.

Ao sul da bacia do rio Negro, entre os grupos pano do sudoeste amazônico, é possível identificar alguns deles. Além dos paralelos entre o "nawa" pano e o "masa" tukano - ambos traduzidos por "gente" e que compõem as extensas séries de etnônimos em seus conjuntos - Philippe Erikson (2004) chamou a atenção entre os Matis para o que seria uma "incompletude intrínseca da vida social", assim como Oscar Calavia Sáez(2002) pôde apreender entre os Yaminawa uma inclinação para ser "o outro dos outros" ao invés de si mesmo. Casos diferentes, e que diferem em conjunto do caso tukano, porém, com ao menos um ponto em comum. Os Matis lançam mão de categorias específicas, a fim de operar uma divisão interna a seu grupo, a qual determina uma sorte de "estrangeiros de dentro" - particularmente, os filhos de mulheres cativas em guerras passadas - ao mesmo tempo em que define outros grupos específicos, como os Marubo, como modalidades de si mesmo, ainda que com eles não se observe qualquer interação. Já os Yaminawa, ao mesmo tempo em que se autodesignam Yura, "corpo", inserem esse termo em um catálogo centrífugo de etnônimos, que incluirá expressões formadas com o termo nawa e que emergem no confronto com variados outros. No primeiro caso, tratase de um tipo de específico de dualismo, que não recorta o grupo em partes isomórficas; no segundo caso, os termos X- ou Y-nawa que os Yaminawa reconhecem para si e remetem à alteridade sem afirmar uma identidade por contraste. Em ambos os casos, alteridade supõe proliferação de diferenças, sem se esgotar na dialética do eu e do outro, ou em esferas concêntricas de identidade e diferença graduais. Nas palavras de Erikson, uma "imperiosa necessidade de melhor controlar as relações com o exterior", mas, poderíamos acrescentar um exterior intensamente multifacetado.

Em outra direção, ao norte da calha do rio Negro, entre os Yanomami, uma situação aparentemente mais simples opõe em bloco a figura de um eu a de um outro genérico, a de yanomam, "gente", à de nape, "estrangeiro", que se refere em primeira instância aos inimi- 
gos que vivem em comunidades além do círculo de aliados de uma comunidade de referência. Esse dispositivo veio a ser transposto para o contexto das relações entre índios e brancos, e nape passou a ser o termo com o qual os Yanomami designam os brancos de modo geral. José Antonio Kelly (2005) veio mostrar que essa extensão do "espaço convencional yanomami" produziu um efeito inovador. Se nape já era de antemão uma categoria relacional, ou posicional, passaria a definir um novo eixo de diferenciação entre os Yanomami. Com isso, grupos do entorno de Ocamo - base missionária e de serviços no rio Orinoco - considerados "yanomami civilizados" face àqueles "yanomami de verdade" (waiká, não civilizados) que vivem à montante, passam, no mesmo movimento, a ser algo, ou em parte, nape. Conforma-se assim aquilo que o autor chama de um "eixo transformacional nape". Nesse eixo, os grupos à jusante, mais próximos aos brancos, são nape para os Yanomami das cabeceiras, mas junto com esses são Yanomami face aos brancos, os nape de verdade. Assim estão permanentemente napeprou, "tornando-se brancos", um ponto ao qual se aproximam sem nunca atingir. Sugere, então, uma descrição dos moradores de Ocamo em termos de uma dualidade yanoami/nape, o que seria mais uma expressão da constituição eu/outro da pessoa, característica das noções ameríndias de personitude. Yanomam para uns, nape para outros, tudo dependendo da perspectiva adotada, à montante ou à jusante. Esse fenômeno difere radicalmente de um processo de mestiçagem, uma mistura que fundiria os dois termos anteriores em um terceiro tipo. Tratar-se-ia, portanto, de "antimestiçagem".

Ainda que de passagem, vale mencionar aqui um caso análogo no distante leste e nordeste do país. Refere-se aos coletivos que vêm sendo chamados de afro-indígena, entre os quais recentemente Márcio Goldman inventariou diferentes situações. Essa outra mistura é explorada por Goldman a partir de seu elemento de indeterminação, das conexões e disjunções possíveis entre os dois polos. O autor sugere que se trata de uma perspectiva que se estabelece na justaposição do afro e do indígena, que se vale de seu caráter analógico (e não digital), constituindo-se de modo radicalmente diferente daquela outra oposição entre afro e/ou indígena, de um lado, e branco, de outro. 
Um agenciamento evidentemente minoritário que se configura como "contramestiçagem" (Goldman, 2015). Sobre a noção de antimestiçagem, talvez esta última apresente alguma vantagem em termos de por em destaque a composição intencional e criativa que subjaz a esses processos.

Entre essas duas situações - a multiplicidade pano e o campo de forças delineado por vetores de anti (ou contra) mestiçagem - talvez possamos situar os povos do rio Negro, e particularmente os Tukano que nos serviram de ponto de apoio. Aqui, uma miríade molecular de nomes coexiste com uma distribuição molar de posições, mas alternando-se nas funções de fundo e forma uma para outra. Ao ativar posições e nomes simultaneamente, os coletivos locais exercem influências recíprocas entre si, impedindo que o sistema se feche em uma totalidade hierárquica. Mas essas formulações abstratas talvez possam ser enunciadas de maneira mais direta: naquele gradiente de personitude do qual se tratou, os polos de humanidade e de não humanidade nunca são ocupados; só há movimentos e pausas ao longo das infinitas possibilidades que constituem o espaço delimitado por esses extremos.

\section{Notas}

1 Versões preliminares deste trabalho foram apresentadas na $36^{\mathrm{a}}$ Reunião Anual da ANPOCS em 2012 e em seminários em Campinas (UNICAMP), Florianópolis (Museu de Antropologia/UFSC) e Rio de Janeiro (IFCS/UFRJ) em 2014. Por essas oportunidades e pelos comentários recebidos agradeço a: Beatriz Perrone-Moisés, Márcio Goldman, Antonio Guerreiro, Oscar Calavia Sáez, Jose Antonio Kelly e Cesar Gordon. A elaboração desta versão final integrou um período de estágio pós-doutoral no PPGAS/Museu Nacional no segundo semestre de 2014, sob a supervisão de Eduardo Viveiros de Castro, a quem agradeço pela acolhida e pelas sugestões. Todos os equívocos são, evidentemente, de minha inteira responsabilidade.

2 A região é até hoje quase que exclusivamente ocupada por grupos indígenas. Além de uma relativamente escassa população não indígena concentrada na cidade de São Gabriel da Cachoeira, composta de comerciantes, funcionários públicos, militares e missionários, habitam ali 21 grupos diferentes, representantes das famílias linguísticas tukano oriental (Cubeo, Desana, Tukano, Miriti-Tapuia, Arapasso, Tuyuka, Makuna, Bará, Siriano, Carapanã, Wanano e Pira-tapuia), arawak (Tariano, Baniwa, Kuripako, Warekena e Baré) e maku (Hupda, Yuhup, Nadeb e Dow) (Cabalzar; Ricardo, 1998). Esses grupos ocupam cerca de 700 povoados de tamanhos variáveis, estabelecidos ao longo dos rios Negro, Uaupés, Tiquié, Papuri, Içana, Aiari, Xié e vários outros afluentes menores, perfazendo uma população total 
de cerca de 30 mil pessoas, montante que incorpora os cerca de 7 a 8 mil índios que vivem na própria sede do município. As bacias desses rios são incluídas em um conjunto de cinco Terras Indígenas contíguas, cuja extensão ultrapassa os 10 milhões de hectares. Essas significativas cifras demográficas e territoriais fornecem os contornos gerais daquilo que vem sendo reiteradamente apontado na literatura etnográfica como um extenso sistema social regional aberto, de fronteiras relativamente indefinidas - englobando extensas porções dos territórios colombiano e venezuelano - cujas unidades compõem um mosaico de identidades sociais. Todos esses povos apresentam como características morfológicas básicas a exogamia e a descendência patrilinear, além de uma subdivisão interna em sibs hierarquizados entre si, cuja distribuição espacial é extremamente variada, sendo poucos os casos em que ainda se verifica sua concentração (ideal) em um mesmo trecho de rio ou em um dado território - ver, com relação aos povos tukano orientais, Goldman (1963/1979), Reichel-Dolmatoff (1971), Hugh-Jones C. (1979), Hugh-Jones S. (1979), Bidou (1976), Arhem (1981), Jackson (1983), Buchillet (1983), Chernela (1993), Lasmar (2005), Andrello (2006) e Cabalzar (2008); para os povos arawak, conferir também Wright (1981), Hill (1993) e Journet (1995).

3 Para uma avaliação dos problemas metodológicos que enfrenta o historiador ao lidar com o tema, ver a interessante discussão de Loureiro Dias (2014).

4 Grande parcela da outra metade era oriunda do rio Japurá, rio este relativamente menor, que corre no mesmo sentido do rio Negro e lança duas águas no baixo Solimões. Ou seja, uma sub-bacia interposta entre as duas maiores do Negro e Solimões. Talvez esse dado explique a total ausência de ocupação humana atualmente no Japurá. As principais referências para quem queira saber mais são: Sweet (1974), Wright (1981; 2005), Meira (1993) e Loureiro Dias (2014).

5 A exceção são os termos "tucano" e "desana", que designam grupos atuais do rio Uaupés, e "macuxi e "wapixana", designações atuais de grupos do alto rio Branco, já no Estado de Roraima. É possível que a presença desses nomes nessa documentação indique o extenso raio de atuação do empreendimento escravagista em meados do século XVIII.

6 Para o final do século XVIII, há informações aparentemente mais precisas, pois fornecidas por viajantes que se encarregam de proceder aos primeiros levantamentos sistemáticos do rio Negro e seus afluentes - Noronha (1759), Xavier de Sampaio (1775) e Ferreira (1776). As listas de etnônimos presente nessas fontes do final do século são significativamente menores. Sua tabulação foi empreendida por Bruzzi da Silva (1977, p. 28-29), que apresenta listas separadas para os rios Negro e Uaupés. Para as povoações do rio Negro, é apontada a presença de 33 grupos diferenciados e, para o rio Uaupés, outros 25. Outras informações, já de meados do século XIX, dão conta da existência de um número menor de categorias em uso nas povoações situadas ao longo do rio Negro: já não são 33, mas 22 nomes, muito embora entre esses figurem seis que não são mencionadas para o século XVIII. Quanto ao rio Uaupés, dá-se o contrário: já não são 25 , mas 49 os termos registrados nas fontes do século XIX.

7 De acordo com o exame efetuado por Bruzzi da Silva (1977), seguem os nomes dos grupos supostamente presentes nos rios Negro e Uaupés entre os século XVIII e XIX:

Século XVIII:

- Rio Negro: Manao, Paraviana, Uaranacocena, Carahiahi, Baré, Passé, Cocuana, Aroaqui, Tacu, Baniba, Baiana, Uariquena, Uaupez, Macú, Mepuri, Marapitana, 
Aruniê, Cubeuana, Coeuana, Duanáis, Jurí, Japíuna, Jaruna, Juma, Mendó, Maquiritare, Puiteno, Pexuma, Termairarí, Turimarí, Uauuana, Xamá e Xapuena.

- Rio Uaupés: Aguará, Arapaxi, Arará, Baniba, Burenari, Cequeno, Goiana, Cubeuana, Cudujari, Cuenacá, Daçaca, Macú, Macucoena, Mueinó, Mamangá, Paicueno, Panenoá, Pumenicá, Quereruri, Cariana, Uacari, Uanana, Uaupé e Urinaná.

Século XIX:

- Rio Negro: Manao, Paraviana, Uaranacocena, Caburicena, Carahiahi, Baré, Passé, Ajuana, Cariás, Cocuana, Aroaqui, Tacu, Tarumã, Baniba, Baiana, Uariquena, Uaupez, Damacuri, Macú, Mepuri, Marapitana e Curanáos.

- Rio Uaupés: Agarani, Arapaço, Baniua, Baúna, Beijú, Boanari, Cainatari, Carapanã, Caua, Uananá, Coró-Coró, Cubeo, Cutia, Deçana, Gi, Giboia, Ipeca, Iravassú, Jacamí, Jurupari, Juruá, Macú, Macucoena, Macuná, Macura, Mamengá, Mirití, Omaua, Onça, Panenoá, Pirá-Tapuia, Piraiurú, Puça, Quaty, Coeuana, Quenacá, Tabaiana, Quatitu, Tanimbuca, Tapiira, Tariana, Tatú, Tijucó, Timanará, Tocandira, Tucano, Uacará, Uaracú e Urinaná.

8 Ver o recente volume sobre os Baré publicado pelo SESC, com a contribuição de vários pesquisadores dedicados à sua história e situação contemporânea, além do relato de duas lideranças baré (Herrero; Fernandes, 2015).

9 De acordo com Meira (2005), “[...] as informações etnonímicas, embora nem sempre confiáveis, demonstram que a população indígena majoritária nas povoações seria, no século XIX, constituída pelos resíduos demográficos dos povos que viviam na região desde a chegada dos europeus, e que haviam sido 'descidos' e aldeados compulsoriamente no século XVIII. E mais, há uma significativa população descendente desses povos, mas que é fruto da miscigenação com os colonizadores, os ditos 'mamelucos', que vivia nas mesmas povoações ao longo de todo o rio Negro".

10"Todavía los grupos aruak del Içana miran a sus vecinos (do Uaupés) con cierto desprecio y le dan a palabra Uaupés um significado despectivo, así como los índios del Caiary no oyen com agrado a designación Uaupés. Por ejemplo, si se le dice a un karútana 'Eres un inútil, un desertor, etc!', por lo general responderá en lingoa geral: 'isché ti(ma) uaupé!' (no soy un uaupé!). Se situa así conscientemente en contraposición a los tradicionales enemigos de estos aruak". Essa informação, embora não permita estabelecer com certeza se a palavra uaupé é de origem arawak, já que está inserida em uma frase na língua geral, dá a entender que se tratava de uma categoria que marcadamente se contrastava à de "tapuia" ou "baré", isto é ela designava por excelência aqueles que permaneciam fora da "civilização". Mas é importante destacar que o informante de Koch-Grunberg era um karutána, subgrupo dialetal baniwa do baixo Içana, cuja grande maioria é hoje falante da língua geral. Portanto o contexto de emprego do termo Uaupé seria aquele em que grupos falantes da língua geral, mas originalmente arawak, se referiam a grupos pertencentes à família linguística tukano. Ora, esse é exatamente o caso dos baré do rio Negro, ou ao menos de uma parte deles. Wright (2005) se inclina a considerar os chamados Boapés como um amálgama de vários grupos, de origem tanto arawak como tukano, que no século XVIII habitavam o rio Uaupés acima das primeiras cachoeiras, mas que não haveriam sobrevivido aos avanços dos portugueses. Becerra (2002) defende que haveriam sido um grupo arawak específico, igualmente extinto antes do final daquele século. Nesse aspecto, parece que a sugestão de Wright é a mais plausível, tendo em vista a persistência da categoria no século XIX como designação genérica para muitos grupos. 
11 Com os quais muitos vieram a se tornar cunhados, "cunhamenas", expressão apontada e explorada por Barbara Sommer (2006).

12 Para uma exposição muito útil e minuciosa quanto ao uso variável dos termos "grupo exógamo", "fratria", "tribo"e "sib" tal como utilizados por Irving Goldman, Jean Jackson e Stephen e Christine Hugh-Jones em suas monografias pioneiras sobre os povos tukano, ver Cabalzar (2008).

13 Insiste-se que o leitor deve ter cuidado em não confundir o grupo ou etnia Tukano propriamente dito com a família linguística tukano, da qual fazem parte os demais grupos mencionados.

14Trata-se da versão uaupesiana do famoso motivo mítico da má-escolha, no qual o ancestral do branco fica com a espingarda e o dos índios com o arco e flecha. No caso do Uaupés, há versões que incluem todas as mercadorias ao lado da espingarda, bem como o conjunto de adornos cerimoniais ao lado do arco e flecha. Ver Andrello (2006).

15Esses nomes próprios assumem em geral duas formas: tal como grafados acima correspondem ao singular, àquele que dá origem a um grupo; no plural, correspondem a nomes para os coletivos.

16Povo muito provavelmente arawak da foz do rio Uaupés extinto já no século XVIII (Wright, 2005). Remanescentes que provavelmente foram incluídos na categoria baré.

17De modo geral, essas etnografias... Por outro lado, há que se mencionar uma exceção que não aparece na narrativa, como os Bará (Jackson, 1983) - não é impossível, no entanto, que possa corresponder a um dos três termos não explicitamente associados a qualquer grupo "etnográfico".

18Com quem transcrevi entre 2001 e 2002 uma versão da narrativa tukano acerca de como o grupo se originou, cresceu e se fixou em diversas localidades dos rios Uaupés, Papuri e Tiquié, bem como sobre a distribuição interna de nomes cerimoniais e apelidos adquiridos em diferentes ocasiões pelos ancestrais fundadores desses clãs. A íntegra dessa narrativa mito-histórica encontra-se em Maia e Maia (2004), volume 7 da Coleção NIRN. Não se trata de uma versão exaustiva, que dá conta de uma história global dessas 36 unidades. Elabora, sobretudo, a trajetória dos quatro primeiros sibs e eventualmente de alguns episódios da trajetória de alguns outros. A rigor, não há versão global. Todas são parciais e, evidentemente, nem sempre coincidentes ou encaixáveis. Todas, porém, mantêm elementos invariantes, cujo exame aguarda maiores esforços.

19De fato, os nomes principais são sempre seguidos de um apelido diferenciador, pois os primeiros compõem um reduzido estoque de sete ou oito termos que aparecem ao longo da jornada da cobra-canoa e se distribuem de maneira não regular ao longo de toda a série de clãs tukano; ou seja, os nomes originários repetem-se ostensivamente, ao passo que se combinam com apelidos específicos que vêm a individualizar os 36 clãs (Andrello, 2015).

20 A expressão privilegiada desse aspecto é, com efeito, o uso da terminologia intergeracional de parentesco no contexto dessas relações. Jean Jackson ( 1983) e Janet Chernela (1993) apontaram o uso de termos como "avô" e "tio" como vocativos que pessoas de grupos de alta hierarquia empregam com relação àqueles situados em patamares inferiores. Esse uso, em princípio surpreendente, explica-se pela diferença relativa de idade no interior da série siblings que dá origem aos clãs de um grupo exogâmico: o irmão mais velho, tendo nascido muito tempo antes que o irmão mais novo, já teria filhos e talvez netos, quando este vem a nascer. Assim, 
ainda que possuindo a mesma idade que os filhos e netos de seu irmão mais velho, ele é chamado por estes de tio ou mesmo avô. De modo correlato, um homem de um grupo hierarquicamente superior é referido por parentes em posição inferior como sobrinho, ou neto. Passa-se, no entanto, que se um determinado clã deixa de crescer ocorrerá com o tempo uma inversão dessas posições. Pois paulatinamente haverá gente de clãs inferiores referindo-se a membros de um clã maior como tios e avôs. Isto é, o crescimento diferencial dos grupos incide diretamente naquilo que é o modo mais explícito de se reconhecer posições hierárquicas. Não crescer significa deixar de ser um neto ou um sobrinho para tornar-se, com o passar do tempo e do ponto de vista de outrem, um tio ou um avô (Andrello, 2015).

21 Esses grupos haveriam deixado a embarcação antes do tempo necessário à sua maturação como gente. Por esse motivo foram castigados, sendo obrigados a permanecer numa região próxima a Ipanoré, mais especificamente no igarapé Japu, vivendo como maku no centro da mata.

\section{Referências}

AIKENVALD, A. Bare: languages of the world/Materials 100. Munchen/ Newcastle: Lincom Europa, 1995.

AIKENVALD. A. Dicionário Tariana-Português e Português-Tariana.

Boletim do Museu Paraense Emílio Goeldi, série Antropologia, [S.l.], v. 17, n. 1, 2001.

ANDRELLO, G. Cidade do Índio: trasformações e cotidiando em Iauaretê. São Paulo: Editora da UNESP; ISA; NuTI, 2006.

ANDRELLO, G. Peixes e pessoas: reflexões sobre o parentesco tukano. In: SEMINÁRIO SEXTAS NA QUINTA, NANSI/PPGAS/Museu Nacional, Rio de Janeiro, novembro/2015. Anais... Rio de Janeiro, 2015. (mss)

ARHEM, Kaj. Makuna Social Organization. A Study in Descent, Alliance and the Formation of Corporate Groups in the North-west Amazon. Stockholm: Almqvist and Wiksell International, 1981.

BECERRA, G. C. La Iglesia en la Frontera: Misiones Católicas en el Vaupés, 1850-1950. Bogotá: Universidad Nacional de Colômbia, 2002.

BIDOU, P. Les fils de l'anaconda celeste. (Lês Tatuyo). Étude de la strutcture socio-politique. 1976. 331 p. Tese (Doutorado $3^{\circ}$ Ciclo) Université de Paris, Paris, 1976.

BRUZZI, A. A civilização indígena do Uaupés. Roma: LAS, [1949] 1977. BUCHILLET, Dominique. Maladie et mémoire des origines chez les Desana du Uaupés: conceptions de la maladie et de la thérapeutique d'une société amazonienne. 1973. 262 p. Tese (Doutorado) - Université de Paris-X Nanterre, 1983. 
CABAlZAR, A.; RICARDO, B. (Org.). Mapa-Livro dos Povos Indígenas do Alto e Médio Rio Negro. São Paulo: ISA \& FOIRN, 1998.

CABALZAR, A. Filhos da Cobra de Pedra: organização social e trajetórias tuyuka no rio Tiquié (noroeste amazônico). São Paulo: Editora da UNESP/ ISA/NuTI, 2008.

CALAVIA SÁEZ, O. Nawa, Inawa. Ilha - Revista de Antropologia, Florianópolis, v. 4, n. 1, p. 36-57, 2002.

CARNEIRO DA CUNHA, M. Pontos de vista sobre a floresta amazônica: xamanismo e tradução. Mana, Rio de Janeiro, v. 4, n. 1, p. 7-22, 1998.

CAYÓN, L. Penso, logo crio: a teoria Makuna do mundo. 2010. 411 p. Tese (Doutorado) - Universidade de Brasília, Brasília, DF, 2010.

CHERNELA, Janet. The Wanano Indians of the Brazilian Amazon: a sense of space. Austin: University of Texas Press, 1993.

CORREA, F. Por el Camino de la Anaconda Remédio. Santafé de Bogotá: Universidade Nacional \& Conciencias, 1996.

DEleuZE , G.; GUATTARI, F. Mil Platôs. São Paulo: Editora 34, 1995. v. 2.

DIAS CABALZAR, F. Até Manaus, até Bogotá: os Tuyuka vestem seus nomes como ornamentos. 2010. 318 p. Tese (Doutorado) - Universidade de São Paulo, São Paulo, 2010.

DIAS, C.; ANDRELLO, G.; ESTERCI, N. Áreas protegidas e identidades étnicas no Médio Rio Negro. In: 25ª REUNIÃO BRASILEIRA DE ANTROPOLOGIA, Goiânia, 2006. Anais..., Goiânia, 2006. p. 1-18, CDROM.

ERIKSON, P. Qu est-ce qu'un ethnonyme? Les Cahiers ALHIM, 10. 2004. Disponível em: <http://alhim.revues.org/index112.html>. Acesso em: 11 ago. 2010 .

FERREIRA, Alexandre Rodrigues. Diário da viagem Philosophica pela Capitania de S. José do Rio Negro com a informação do estado presente: pelo Dr. Alezandre Rodrigues, [1776] 1885.

FERREIRA, Alexandre Rodrigues. Naturalista empregado na expedição philosophica do Estado, em 1775-6. Revista do IHGB, Rio de Janeiro, Tomo 48, 1775-76.

GOLDMAN, I. The Cubeo: Indians of the Northwest Amazon. Urbana: University of Illinois Press, [1963] 1979.

GOLDMAN, M. Quinhentos Anos de Contato: por uma teoria da (contra) mestiçagem: Aula proferida para progressão para Professor Titular, PPGAS/Museu Nacional/UFRJ, Rio de Janeiro, março de 2015. (mss). 
HERRERO, M.; FERNANDES, U. (Org.). Baré: povo do rio. São Paulo: Edições SESC, 2015.

HILL, J. Keepers of Sacred Chants: the poetics of ritual power in an amazonian society. Tucson: The University of Arizona Press, 1993.

HUGH JONES, C. From the Milk River: Spatial ad Temporal Processes in North-west Amazonia. Cambridge: Cambridge University Press, 1979.

HUGH-JONES, S. The Palm and the Pleiades. Cambridge: Cambridge University Press, 1979.

HUGH-JONES, S. Nomes Secretos e Riqueza Visível: nominação no Noroeste Amazônico. Mana, Rio de Janeiro, v. 8, n. 2, p. 45-68, 2002.

HUGH-JONES, S. Caixa de Pandora: estilo alto-rio-negrino. R@U Revista de Antropologia da UFSCar, São Carlos, v. 6, n. 1, p. 155-173, 2015.

JACKSON, J. The Fish People. Linguistic Exogamy and Tukanoan Identity in Northwest Amazonia. Cambridge: Cambridge University Press, 1983.

JOURNET, N. Les paix des jardins. Structures sociales des Indiens curripaco du haut Rio Negro. Paris: Institut d'ethnologie, 1995.

KELLY, J. A. Notas para uma teroria do "virar branco". Mana, Rio de Janeiro, v. 11, n. 1, p. 202-234, 2005. (mss)

KELLY, J. A. The captive dominator and the becomer: an essay on criollo and indigenous mistures, history and social forms. Florianóplis, 2014. (mss).

KOCH-GRUNBERG, T. Dos Años entre los Indios. Santafé de Bogotá: Universidad Nacional de Colombia, [1909/10] 1995. v. 2.

LASMAR, C. De volta ao Lago de Leite. São Paulo: UNESP/ISA/NuTI, 2005.

LIMA, T. O dois e seu múltiplo. Reflexões sobre o perspectivismo em uma cosmologia tupi. Mana, Rio de Janeiro, v. 2, n. 2, p. 21-47, 1996.

LOLI, P. As redes de trocas rituais dos Yuhupdeh no igarapé

Castanha, através dos benzimentos e das flautas Jurupari. 2010.

206 p. Tese (Doutorado) - Universidade de São Paulo, São Paulo, 2010.

LOUREIRO DIAS, C. O Livro das Canoas - uma descrição. In: IV ENCONTRO INTERNACIONAL DE HISTÓRIA COLONIAL, Belém. Anais..., Belém, PA, 2014. p. 57-70.

MAIA, M.; MAIA, N. łsa Yekisimia Masinsehé: a sabedoria de nossos antepassados, uma narrativa oyé. São Gabriel da Cachoeira: FOIRN, 2004.

MAIA, P. Desequilibrando o convencional: estética e ritual com os Baré 
do alto rio Negro (AM). 2009. 315 p. Tese de Doutorado, Museu Nacional/ UFRJ, 2009.

MEIRA, M. O Tempo dos Patrões: extrativismo da piaçava entre os índios do rio Xié. 1993. 127 p. Dissertação (Mestrado) - Universidade de Campoinas, Campinas, SP, 1993.

MEIRA, M.. Índios e Brancos nas Águas Pretas: Histórias do Rio Negro. In: FORLINE, Louis Carlos; MURRIETA, Rui Sergio Sereni; VIEIRA, Ima Célia Guimarães. (Org.). Amazônia Além dos 500 Anos. Belém: Museu Paraense Emílio Goeldi, 2005. p. 183-226.

NIMUENDAJU, C. Reconhecimento dos rios Içana, Ayari e Uaupés. In: ARAÚJO MOREIRA NETO, C. de (Org.). Curt Nimuendaju: textos indigenistas. São Paulo: Edições Loyola, [1927] 1982. p. 123-191.

NORONHA, José Monteiro. Roteiro de viagem da cidade do Pará até as últimas colônias dos domínios portugueses em os rio Amazonas e Negro: ilustrado com algumas notícias que podem interessar a curiosidade dos navegantes e dar mais claro conhecimento das duas capitanias do Pará e de S. José do Rio Negro. Lisboa: Academia Real das Sciencias, [1756] 1856.

REICHEL-DOLMATOFF, G. Amazonian Cosmos: the Sexual and Religious Symbolism of the Tukano Indians. Chicago: University of Chicago Press, 1971.

RIBEIRO DE SAMPAIO, Ouvidor Francisco Xavier. Diário da viagem que em visita e correição das povoações da Capitania de S. José do Rio Negro fez o Ouvidor e Intendente Geral da mesma Francisco Xavier Ribeiro de Sampaio, no anno de 1774 e 1775. Lisboa: Tipographia da Academia, [1774-75] 1825.

SOMMER, B. Cracking Down on the Cunhamenas: Renegate Amazonian Traders under Pombaline Reform. Journal of Latin American Studies, [S.l.], v. 38. p. 767-791, 2006.

SORENSEN, A. Multilingualism in the Northwest Amazon. American Anthropologist, [S.l.], v. 69, p. 670-684, 1967.

SWEET, D. A Rich Realm of Nature Destroyed: the Middle Amazon Valley, 1640-1750. 1974. 835 p. Tese (Doutorado) - The University of Wisconsin. Ann Arbor: The University of Microfilms International, 1974.

VIVEIROS DE CASTRO, E. Os pronomes cosmológicos e o perspectivismo ameríndio. Mana, [S.l.], v. 2, n. 2, p. 115-144, 1996.

VIVEIROS DE CASTRO, E. Zeno and the Art of Anthropology. Of Lies, 
Paradoxes, and Other Truths. Common Knowledge, [S.l.], v. 17, n. 1, p. 128-145, 2012.

WAGNER, Roy. The Fractal Person. In: STRATHERN, Marilyn; GODELIER, Maurice. (Org.). Big Men and Great Men: Personifications of Power in Melanesia. Cambridge: Cambridge University Press, 1991. Disponível em: $<$ http://pontourbe.revues.org/173>. Acesso em: $1^{\circ}$ out. 2016.

WAGNER, R. Há grupos sociais na Nova Guiné. Cadernos de Campo, [S.l.], v. 19, p. 237-257, [1974] 2010.

WRIGHT, Robin. History and Religion of the Baniwa Peoples of the Upper Rio Negro Valley. 1981. 630 p. Tese (Doutorado) - Stanford University, 1981.

WRIGHT, R. História indígena do Noroeste da Amazônia: hipóteses, questões, e perspectivas. In: CARNEIRO DA CUNHA, M. (Org.). História dos índios no Brasil. São Paulo: FAPESP/Companhia das Letras/SMC, 1992. p. 253-266.

WRIGHT, R. Escravidão Indígena no Noroeste Amazônico. In: WRIGHT, R. História Indígena e do Indigenismo no Alto Rio Negro. Campinas: Mercado de Letras, 2005.

Recebido em 15/06/2015

Aceito em 10/03/2016 